\title{
Assessment of Erosive Activity by Modeling Approach in Northern
}

\section{Algeria}

\author{
Received : $14 / 10 / 2021$ \\ Acceptance : 26/11/2021 \\ Available online: $31 / 12 / 2021$
}

\author{
Rachid CHELLALI ${ }^{\text {a) }}$ and Rabah LADJAL ${ }^{\text {b) }}$ \\ University of Tissemsilt, Algeria. \\ ${ }^{a)}$ Corresponding Author: chellalidoc@gmail.com \\ b) rabahmag@yahoo.fr
}

\begin{abstract}
The erosive activity in the Cheliff watershed (Algeria) draws its magnitude from the climatic, geological and geomorphometric conditions that characterize this region. Indeed, the high spatio-temporal variability of precipitation caracterising the semi-arid climate, coupled at a very pronounced relief with vulnerable lithologic composition amplified the phenemon. The extended no taring of the main hydrometric station, located at the exutory of Nahr Ouassel sub-watershed, makes inevitable the use of quantification by modeling. Moreover, the endoreism of the flows in the sub-basin prevents any significant correlation between rainfall and flows, which justifies the extrapolation of an adequate model. The regional model adopted in this study was established from the data of several hydrometric stations and dams through northern Algeria. The Bougara dam sub-basin was used for its validation. The main objective of this work is to estimate the specific degradation of Nahr Ouassel sub-watershed using an adequate model.
\end{abstract}

Keywords. Cheliff, Endoreism, Model, Correlation, Nahr Ouassel.

\section{INTRODUCTION}

Hydric erosion generated by the runoff is a widespread phenomenon in different Mediterranean countries. It continues to take considerable proportions especially in the semi-arid regions because of slopes, torrential rains, high vulnerability of land and unfavorable impact of agricultural activities. The situation continues to deteriorate; In Tunisia and Morocco the total area threatened by water erosion is respectively $40 \%$ and $45 \%$ [1] and in Algeria about 45\% of the Tellian zones are affected, [2]. In Algeria, the sediment transport exported downstream every year a large quantity of sediments which affect the hydraulic works by rapid siltation and causes significant agricultural soil damage.

For quantification purposes, many researchers have developed relationships linking solid transport with geomorphological and climatological factors for some Algerian watersheds like [3-7].

As for, Demmak [8] and Meddi [9] have developed estimated models of specific degradation for a large scale in the north of Algeria.

It should be noted that despite the existence of hydrometric stations, the series are often unusable because of their derating as is the case of Kef Lasfer station located at the exutory of the sub- watershed of Nahr Ouassel.

The main objective of this work is to determine the specific degradation of Nahr Ouassel watershed using an adequate model and the prescription of some measures wrestling against this phenomenon.

\section{MATERIAL AND METHODS}

\section{- Presentation of the Study Zone}

The Nahr Ouassel watershed covers $3110 \mathrm{~km}^{2}$ of area in the Cheliff upstream of Boughzoul. It is drained from west to east by the wadi of Nahr Ouassel itself, originated of the region of Tiaret (Algeria). Its exutory is controlled by the Kef Lasfer station at the confluence with wadi Touil (Fig.1). It consists of a vast plain called "plateau of Sersou' with $950 \mathrm{~m}$ of altitude. This plain is strewn with depressions or Daïa that trap important surface runoff. The average annual rainfall in the watershed is $359 \mathrm{~mm}$; the main annual evapotranspiration is $1550 \mathrm{~mm}$. The average annual temperature is about $14.7^{\circ} \mathrm{C}$. The bioclimate of the watershed belongs to the semi-arid stage with cold winter [10]. 


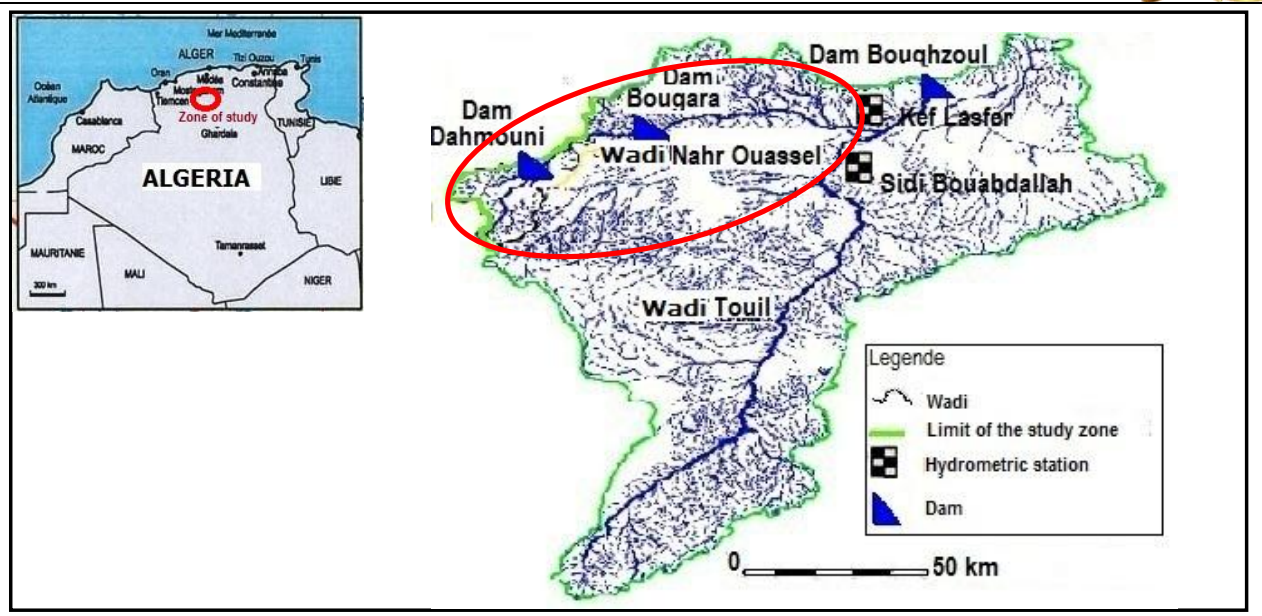

FIGURE 1. Localization of the study zone (Cheliff upstream of Boughzoul) [10].

\section{- Selection of the Model}

a) Basic data of the model

Based on the data of 67 hydrometric stations and dam in northern Algeria, the author Meddi [9] has developed a regional model that relates the annual specific degradation, the average annual liquid flow, monthly rainfall and controlled area of watersheds.

The specific degradation of the watersheds was calculated from the bathymetric surveys recorded at different dates and measured by the National Agency for Dams and Transfers (ANBT). The specific degradation observed (Dsobsr) at the outlet of the watersheds was calculated from the measurements carried out at the hydrometric stations managed by the National Hydric Resources Agency (ANRH).

b) Tested models

The regression models were selected on the basis of the coefficient of determination $\left(\mathrm{R}^{2}\right)$, the NASH criterion, the mean square error (RRMSE). TABLE 1 summarizes the different regression models tested. The best model is selected on the basis of the highest value of the coefficient of determination and the lowest of the NASH criterion [11].

Model 1 gives the best NASH values in calibration and validation, as well as the coefficient of determination. This model will be used to calculate the specific degradation.

TABLE 1. Tested models [9].

\begin{tabular}{|c|c|c|c|c|c|c|}
\hline \multirow{2}{*}{$\mathrm{N}^{\circ}$} & \multirow{2}{*}{ Models } & \multirow{2}{*}{$\mathrm{R}^{2}$} & \multicolumn{2}{|c|}{ NASH (\%) } & \multicolumn{2}{|c|}{ RRMSE } \\
\hline & & & Calib & Valid & Calib & Valid \\
\hline 1 & $\mathrm{Ds}=16115.58 \mathrm{Ql}^{0.67} * \mathrm{~S}^{-0.52} \mathrm{MFI}^{0.10}$ & 0.773 & 77 & 88 & 0.428 & 1.375 \\
\hline 2 & $\mathrm{Ds}=2.14 \mathrm{MFI}{ }^{1.29} \mathrm{~S}^{0.09}$ & 0.383 & 40 & 50 & 0.981 & 3.907 \\
\hline 3 & $\mathrm{Ds}=12.55 \mathrm{Ql}^{0.30} \mathrm{MFI}^{1.01}$ & 0.589 & 52 & 41 & 0.737 & 3.214 \\
\hline
\end{tabular}

With:

Ds: Specific degradation $\left(\mathrm{t} / \mathrm{km}^{2} . \mathrm{yr}\right)$

Q1: Annual inflow $\left(\mathrm{m}^{3} / \mathrm{s}\right)$,

$\mathrm{S}$ : Surface of watershed $\left(\mathrm{km}^{2}\right)$

NASH criterion $(\%)=\left[1-\Sigma(\sqrt{ } \text { Dsobs }-\sqrt{ } \text { Dscal })^{2} / \Sigma(\sqrt{ } \text { Dsobs }-\sqrt{ } \text { Dsobs })^{2}\right] \times 100$

RRMSE: Average quadratic error $(\%)=1 / \mathrm{N} \Sigma_{\mathrm{i}=1}[($ Dsobs - Dscal $) / \mathrm{Dsobs}]$

MFI: Modified Fournier index

\section{- Modified Fournier Index (MFI)}

The index of distribution of precipitations (FI) defined by Fournier [12] was modified by Arnoldus [13] to take into account the precipitations of all the months of the year (pi). He obtained satisfactory results for 164 stations in the United States and for 14 stations in West Africa.

$$
M F I=\sum_{i=1}^{12} \frac{p i^{2}}{P}
$$

By studying solid transport in thirteen watersheds in northwestern Algeria, Meddi [14] showed the predominance of the Modified Fournier Index (MFI), compared to other index in the representation of aggressiveness of the rains.

By reformulating this index the authors Meddi and Toumi [15-16] were able to develop a relationship to calculate:

With:

$$
M F I=0.43 P^{0.49} X^{-0.09}
$$

\section{P: Annual rainfall in mm}

$\mathrm{X}$ : Longitude in $\mathrm{km}$ 


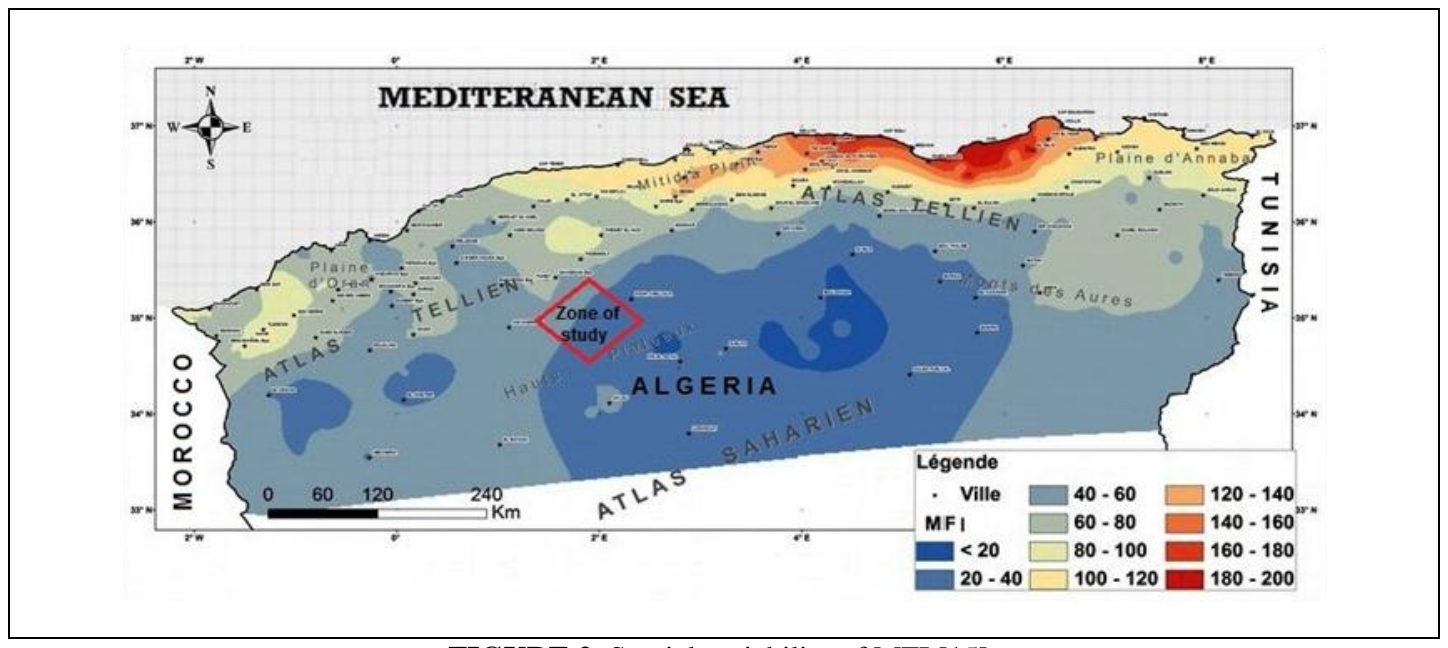

FIGURE 2. Spatial variability of MFI [15].

a) Validation of the model

Thanks to its location (upstream of Kef Lasfer station) and its characteristics in particular hydro climatological, the sub watershed of dam Bougara presents the best conditions of representation of Nahr Ouassel, to validate the selected model:

$$
\mathrm{Ds}_{0}=16115.58 \mathrm{Ql}_{0}{ }^{0.67} * \mathrm{~S}_{0}^{-0.52} \mathrm{MFI}_{0}{ }^{0.10}
$$

To validate this model we have to compare the annual liquid inflow calculated by the model in Bougara watershed at the annual liquid inflow measured at the dam of Bougara.

- Deduction of the Specific Degradation of Bougara sub Watershed From Bathymetric Measures (Ds $s_{0}$ )

According to the bathymetric measures [17], the annual rate of loss at the level of the restraint of dam Bougara is estimated at $0.1 \mathrm{hm}^{3}$. With a soil density $=1.3[18]$

The specific degradation will be:

With:

$$
\mathrm{Ds}_{0}=\mathrm{Aps}_{0} / \mathrm{S}_{0}
$$

$\mathrm{Aps}_{0}$ : Average annual solid inflow $\mathrm{Aps}_{0}=0.1 * 1.3=130000$ tons $/ \mathrm{yr}$

$\mathrm{S}_{0}$ : Surface of Bougara dam sub-basin $=450 \mathrm{~km}^{2}$

$\mathrm{Ds}_{0}$ : Spécific dégradation $\mathrm{t} / \mathrm{km}^{2}$

$$
\mathrm{Ds}_{0}=\mathrm{Aps}_{0} / \mathrm{S}_{0}=289 \mathrm{t} / \mathrm{km}^{2} \cdot \mathrm{yr}
$$

Deduction of the annual liquid inflow of Bougara watershed by the model $\left(\mathrm{Apl}_{0}\right)$

$$
\begin{aligned}
\mathrm{Ds}_{0} & =16115.58 \mathrm{Ql}_{0}{ }^{0.67} * \mathrm{~S}_{0}^{-0.52} \mathrm{IMF}_{0} \\
\mathrm{Ql}_{0} & =0.158 \mathrm{~m}^{3} / \mathrm{s} \Rightarrow \mathrm{Apl}_{0}=4.98 \mathrm{hm}^{3} / \mathrm{yr}
\end{aligned}
$$

Average annual liquid inflow measured at dam Bougara.

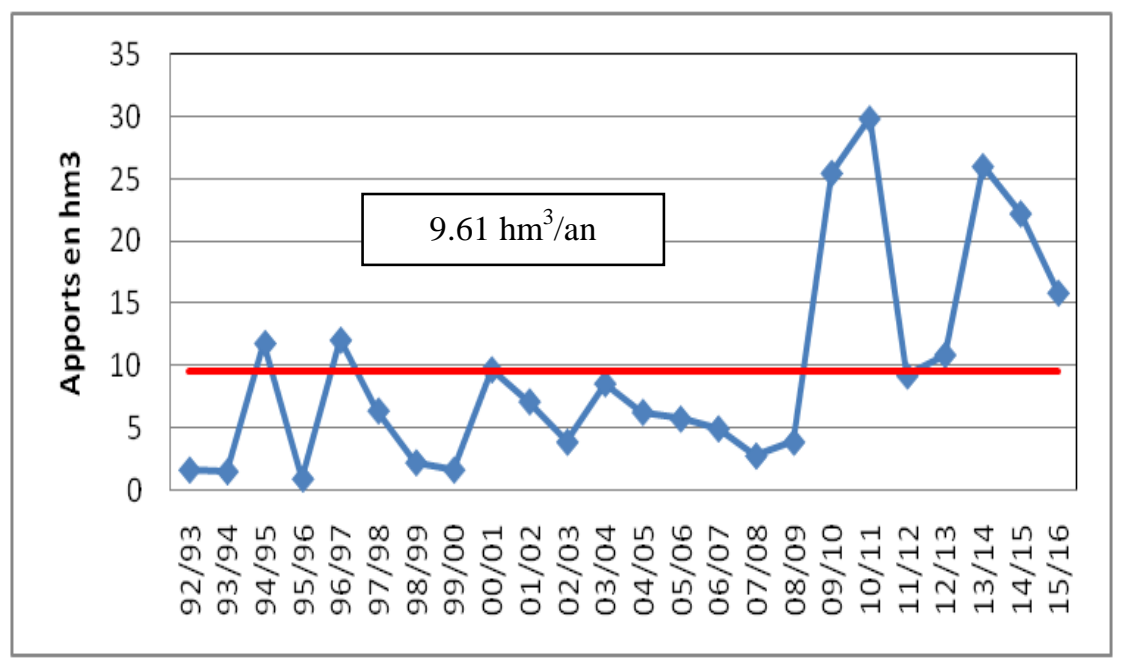

FIGURE 3. Annual Variation of liquid inflow at dam Bougara. 
It should be noted that the liquid contribution recorded at the Bougara dam $\left(9.61 \mathrm{hm}^{3} /\right.$ year $)$ is not the real volume of the sub basin (Fig.3). It turns out that an important part of this contribution represents the treated urban waste water of the city of Tissemsilt which amount $5 \mathrm{hm}^{3} /$ year [10-19]. It should be also noted that the source (Bni Chaib Dam) of the city's drinking water supply is located outside of the study zone. [19]

The average real annual liquid inflow of Nahr Ouassel watershed is $\mathrm{Apl}_{\mathrm{r}}$ :

$$
\mathrm{Apl}_{\mathrm{r}}=9.62-5=4.62 \mathrm{hm}^{3} / \mathrm{yr}
$$

As the relative error of the $\mathrm{Apl}_{0}$ model is low than $10 \%\left(\mathrm{Apl}_{0}\right.$ model $4.98 \mathrm{hm}^{3}>\mathrm{Apl}_{\mathrm{r}}$ measured at dam Bougara $\mathrm{hm}^{3}$ ), this model can be considered to be ideal for estimating the average annual liquid inflow of Nahr Ouassel sub-basin controlled by the Kef Lasfer station.

\section{- Causes of Sediment Mobilization in Nahr Ouassel}

Among the parameters that support erosive activity in the sub-watershed of Nahr Ouassel [10]:

A very pronounced spatial-temporal variability of precipitation across the basin, characterized by a semi-arid climate with intense and irregular rainfall.

A very pronounced relief with a specific gradient $\mathrm{Ds}=228.39$, qualified fairly strong (order $\mathrm{N}^{\circ}$ 5) by the O.R.S.T.O.M classification

A highly developed hydrographic network in the north where the drainage density is $\mathrm{Dd}=0.67$.

A highly lithologic composition vulnerability to erosion characterized by continental deposits over several tens of meters of gravel, sand and silt, crowned by a tuffaceous crust.

\section{RESULTS AND DISCUSSION}

- Calculation of the Average Annual Liquid Inflow of Nahr Ouassel sub Watershed by the Selected Model

$$
\mathrm{Ds}_{1}=16115.58 \mathrm{Ql}_{1}{ }^{0.67} * \mathrm{~S}_{1}{ }^{-0.52} \mathrm{MFI}_{1}{ }^{0.10}=>\mathrm{Ql}_{1}=0.709 \mathrm{~m}^{3} / \mathrm{s}
$$

With:

$\mathrm{Ds}_{1}$ : Specific degradation deducted from the bathymetry measured at the dam of Bougara $\left(289 \mathrm{t} / \mathrm{km}^{2} \cdot \mathrm{yr}\right)$

$\mathrm{S}_{1}$ : Surface controlled by the kef Lasfer station $\mathrm{S}_{1}=3110 \mathrm{~km}^{2}$

$\mathrm{MFI}_{1}$ : Modified Fournier index deducted from the map $\mathrm{MFI}_{1}=50$ (Fig.2) .

Let be an average annual liquid inflow of Nahr Ouassel sub watershed $\mathrm{Apl}_{1}=22.36 \mathrm{hm}^{3} /$ year.

a) Estimate of the Specific degradation in Nahr Ouassel sub watershed .

C : Average annual sediments concentration measured by ANRH at Kef Lasfer Station .

$\mathrm{Apl}_{1}$ : Annual liquid inflow calculated by the model at Kef Lasfer station.

$\mathrm{Aps}_{1}$ : Annual solid inflow estimated at Kef Lasfer station .

$$
\begin{gathered}
\mathrm{C}=29.27 \mathrm{~g} / \mathrm{l}[10] \\
\mathrm{Aps}_{1}=\mathrm{C}^{*} \mathrm{Apl}_{1}=654533 \text { tons/year }
\end{gathered}
$$

$\mathrm{Ds}_{1}$ : Specific degradation in Nahr Ouassel watershed

$$
\mathrm{Ds}_{1}=\mathrm{Aps}_{1} / \mathrm{S}_{1}=210 \mathrm{t} / \mathrm{km}^{2} \text {.year }
$$

- The real measure of the annual volume regularized by the dam of Bougara as well as its bathymetry allowed validating the selected model.

- The measures of sediment concentrations performed by the national agency of hydric resources were exploited to assess the annual total solid inflow of Nahr Ouassel watershed [10].

- As the annual solid inflow of the sub-watershed of dam Bougara is deducted from bathymetry, the bed load is included in the $\mathrm{Ql}_{1}$ calculation.

\section{CONCLUSION}

The modelling approach to estimate the sediment transport allowed highlighting the importance of erosive activity in Nahr Ouassel sub basin despite the absence of hydrometric measurements and the endoreism which prevents any significant correlation between rainfall and flows. The average annual solid inflow resulting (654533 t/year), expresses a high specific degradation rate equivalent to $210 \mathrm{t} / \mathrm{km}^{2}$.year.

The silting up of dams, the clogging of draining devices, the silting up of irrigation canals and the degradation of water and soil quality are the main negative effects of sediment transport, which must be fought by well adapted combination of biological and mechanical techniques. 


\section{REFERENCES}

[1] Chevalier JJ., Pouliot J., Thomson K., Boussema M. R. (1995) : Système d'aide à la planification pour la conservation des eaux et des sols (Tunisie), Système d'information géographique utilisant les données de télédétection, Act du colloque scientifique international, Hammamet. Tunisie, 1-Novembre 1994, 4-12.

[2] Chebbani R., Djelil K., Rosse E. (1999) : Etude des risques d'érosion dans le basin versant Isser, Algérie. Bulletin Réseau Erosion 19: 85-95.

[3] Achite M., Meddi M. (2005): Variabilité spatiotemporelle des apports liquide et solide en zone semiaride. Cas du bassin versant de l'oued Mina (nord-ouest algérien), Revue des sciences de l'eau, $18: 37-56$.

[4] Touaibia B., Aidaoui A., Gomer D., Achite M. (2001) : Quantification et variabilité temporelles de l'écoulement solide en zone semi-aride, de l'Algérie du Nord, Hydrolog Sci J, 46:1, 41-53, DOI:10.1080/02626660109492799

[5] Benkhaled A., Remini B. (2003): Analyse de la relation puissance débit solide débit liquide à l'échelle du bassin-versant de l'oued Wahrane (Algérie), Rev. Sci. Eau, 16 (3), 333-356.

[6] Bouchelkia H., Belarbi F., Remini B. (2013): Estimated Flows of Suspended Solids by the Statistical Analysis of Outfall Drainage Basin of Tafna (Algeria) Soil \& Water Res., 8, 2013 (2): 63-70.

[7] Guidoum A., Nemouchi A., Hamlat A. (2014): Modeling and mapping of water erosion in northeastern Algeria using a seasonal multicriteria approach Arab J Geosci (7), pp 3925-3943

[8] Demmak A. (1982) : Contribution à l'étude de l'érosion et des transports solides en Algérie septentrionale. Thèse de Docteur Ingénieur, université de Pierre et Marie Curie, Paris XI

[9] Meddi M (2015) : Contribution à l'étude du transport solide en Algerie du nord. Larhyss Journa. 24:315-336.

[10] Chellali R., Guendouz A. (2017): Problematic of surface water mobilization and its impact on sustainable development in the Cheliff watershed upstream of Boughzoul, [Ph.D. Thesis.] University of Bab-Ezzouar, Algeria. p239.

[11] NASH J. E. (1969): A course of lectures on parametric or analyticalhydrolog. Great Lakes Institute. University of Toronto Pr 38 : Lecture 12

[12] Fournier F. (1960) : Climat et érosion, la relation entre l'érosion du sol par l'eau et les précipitations atmosphériques. P.U.F., Paris, p201.

[13] Arnoldus H.M.J. (1980): An approximation of the rainfall factor in the Universal Soil Loss Equation. In: De boodt M and Gabriels D (eds) Assessment of erosion,John Wiley and Sons, New York, 127-132.

[14] Meddi M. (2013): Sediment transport and rainfall erosivity evolution in twelve basins in Central and Western Algeria. Journal of Urban and Environmental Engineering, 7: 253-263.

[15] Meddi M., Toumi S. (2014): Regionalisation of rainfall erosivity in northern Algeria. Int. J. Hydrology Science and Technology, (4), No. 2.

[16] Meddi M., Toumi S., Assani A. (2016): Spatial and temporal variability of the rainfall erosivity factor in Northern Algeria Arab J Geosci 9: 282. https://doi.org/10.1007/s12517-015-2303-8

[17] Hydrodragage systems. (2005) : Rapports techniques, levés bathymétriques des barrages en exploitation. Dahmouni, Bougara and Boughzoul.

[18] SOGREAH .(1986) : Etude d'avant-projet détaillé du barrage Colonnel Bougara sur l'oued Nahr Ouassel p50.

[19] Agence nationale de l'aménagement du territorial (A.N.A.T), Délégation de Chlef (2012) : Plan d'aménagenent du territoire de la wilaya de Tissemsilt: Etat, diagnostic et prospective p252. 